\title{
Potensi Bacillus thuringiensis dari Tanah Perkebunan Batu Malang sebagai Bioinsektisida terhadap Larva Spodoptera litura F.
}

\author{
Afriha Mafazah dan Enny Zulaika \\ Departemen Biologi, Fakultas Ilmu Alam, Institut Teknologi Sepuluh Nopember (ITS) \\ e-mail:enny@bio.its.ac.id
}

\begin{abstract}
Abstrak-Bacillus thuringiensis merupakan bakteri gram positif berspora penghasil protein toksin yang bersifat insektisidal, salah satunya terhadap Spodoptera litura $F$. dari Ordo Lepidoptera. Tujuan dari penelitian ini adalah mengetahui daya bunuh $B$. thuringiensis terhadap daya bunuh larva $S$. litura $F$. stadium instar 3, instar 4 dan instar 5. Sumber inokulum $B$. thuringiensis diambil dari tanah perkebunan Batu Malang. Isolasi menggunakan medium selektif LB (Luria Bertani) agar. Isolat terpilih di identifikasi dengan panduan Bergey's Manual of Determinative Bacteria dan pengamatan kristal protein. Isolat K2 dan $K 9$ teridentifikasi sebagai $B$. thuringiensis. Aplikasi bioinsektisida kultur $B$. thuringiensis dalam medium Luria Bertani cair (72 jam) dengan kepadatan sel $10^{7}$. Isolat disemprotkan ke pakan larva instar 3, 4 dan 5. Kematian larva $S$. litura sudah mulai terjadi pada hari pertama setelah aplikasi $B$. thuringiensis dan presentase kematian meningkat sampai tujuh hari. Hampir seluruh larva yang diuji mengalami kematian antara $70-100 \%$.
\end{abstract}

Kata Kunci-Bacillus thuringiensis, Bioinsektisida, Kristal protein, Spodoptera litura.

\section{PENDAHULUAN}

$\mathrm{U}$ LAT grayak (Spodoptera litura F.) merupakan salah satu hama daun yang mempunyai kisaran inang beragam diantaranya kedelai, kacang tanah, kubis, ubi jalar, kentang, sawi dan lain-lain. S. litura F. menyerang tanaman budidaya pada fase vegetatif yaitu memakan daun tanaman yang muda sehingga tinggal tulang daun saja [1]. Pemberantasan hama biasanya menggunakan insektisida kimia. Penggunaan insektisida kimia secara terus menerus tanpa melihat kondisi ekosistem dapat menimbulkan dampak negatif yaitu terjadinya resistensi hama, insektisida dapat terakumulasi dalam tanaman sehingga berbahaya bagi konsumen dan mencemari lingkungan [2].

Aplikasi insektisida dapat menyerang spesies yang bukan sasaran. Perbedaan komposisi kimia dan teknik aplikasi insektisida yang satu dengan yang lainnya membawa efek yang berbeda pula pada populasi yang bukan sasarannya, termasuk para pekerja, konsumen, burung, lebah maupun serangga yang menguntungkan [3], alternatifnya dapat dikembangkan insektisida yang ramah lingkungan berupa bioinsektisida. Salah satu sumber bioinsektisida ialah mikroorganisme tanah seperti Bacillus thuringiensis. Menurut [4], B. thuringiensis dikenal sebagai agensia bahan baku pestisida yang yang baik dalam pertanian, aman terhadap kesehatan konsumen dan ramah lingkungan.
B. thuringiensis adalah bakteri gram-positif, berbentuk batang yang memproduksi kristal protein pada saat sporulasi [5]. Kristal protein tersebut dinamakan $\delta$-endotoksin (protein Cry) yang bersifat lethal jika dimakan oleh serangga yang peka [6]. Ketika masuk ke dalam pencernaan, $\delta$-endotoksin masih dalam bentuk molekul yang besar dan masih dalam bentuk protoksin yang tidak aktif dan akan aktif pada lingkungan basa [7]. Kristal ini sebenarnya hanya merupakan protoksin yang jika larut dalam usus serangga akan berubah menjadi poli-peptida yang lebih pendek (27-149 kd) serta mempunyai sifat insektisidal. Toksin yang telah aktif berinteraksi dengan sel-sel epithelium di midgut serangga. Toksin B. thuringiensis menyebabkan terbentuknya pori-pori (lubang yang sangat kecil) di sel membran di saluran pencernaan dan mengganggu keseimbangan osmotik dari selsel tersebut. Karena keseimbangan osmotik terganggu, sel menjadi bengkak dan pecah dan menyebabkan matinya serangga [5].

Kristal protein yang dihasilkan oleh $B$. thuringiensis juga menyebabkan pembengkakan, pengelupasan, dan kerusakan pada sel-sel epitel usus tengah ulat grayak. Perubahan yang mendasar pada sel-sel usus tengah yang terinfeksi, yaitu adanya pembesaran inti, perubahan retikulum endoplasma hingga konfigurasinya menyerupai vakuola, serta peluruhan atau tidak bersatunya mikrofili [8]. Sebagian strain dapat digunakan untuk bioinsektisida pada larva Ordo Lepidoptera [5]. Oleh karena itu, penelitian ini bertujuan untuk mengetahui potensi daya bunuh $B$. thuringiensis sebagai bioinsektisida untuk membunuh larva $S$. litura F. stadium instar 3, 4 dan 5.

\section{METODOLOGI PENELITIAN}

\section{A. Waktu dan Tempat}

Penelitian ini dilakukan di Laboratorium Mikrobiologi dan Bioteknologi serta Laboratorium Zoologi, Departemen Biologi, Fakultas Matematika dan Ilmu Pengetahuan Alam, Institut Teknologi Sepuluh Nopember, Surabaya pada bulan Januari- Juni 2017.

\section{B. Cara Kerja}

Penelitian ini terdiri atas beberapa tahapan yakni isolasi dan purifikasi, generic assignment dan pengamatan kristal protein serta aplikasi $B$. thuringiensis terhadap larva $S$. litura F. instar 3, 4 dan 5. Tahapan tersebut akan dijelaskan sebagai berikut: 


\section{Isolasi dan Purifikasi}

Isolasi dilakukan dengan cara mensuspensikan sebanyak 1 gram sampel ke dalam $10 \mathrm{ml}$ garam fisiologis $0,85 \%$ steril dalam tabung reaksi, kemudian dihomogenkan. Selanjutnya dilakukan pengenceran sampai dengan $10^{-6}$ [9]. Suspensi dipanaskan pada waterbath pada suhu $80^{\circ} \mathrm{C}$ selama 15 menit [10]. Sebanyak $0,1 \mathrm{ml}$ secara aseptik diinokulasikan ke dalam media selektif Luria Bertani (LB) agar menggunakan pipet mikro dengan metode spread plate. Diinkubasi pada suhu ruang selama 48 jam (Rusmana dan Hadietomo, 1994). Pada medium Luria Bertani, per liter mengandung $10 \mathrm{~g}$ tripton, $5 \mathrm{~g}$ yeast extract, $10 \mathrm{~g} \mathrm{NaCl}$ dalam $15 \mathrm{~g}$ agar [4]. Keberhasilan isolasi ditandai dengan koloni yang tumbuh di media.

Koloni yang tumbuh dipurifikasi sampai diperoleh kultur murni. Satu ose diambil secara aseptis, diinokulasikan ke media LB agar dengan metode 16 goresan dan diinkubasi pada suhu ruang \pm 24 jam. Koloni yang tumbuh diamati sampai diperoleh koloni yang seragam. Validasi kemurniannya dilakukan dengan melihat bentuk sel menggunakan pewarnaan sederhana methylene blue yang diamati di bawah mikroskop perbesaran 1000 kali [9]. Jika bentuk sel sudah seragam, diasumsikan isolat bakteri telah murni.

\section{Generic Assigment dan Pengamatan Kristal Protein}

Isolat terpilih diidentifikasi berdasarkan buku panduan Bergey's Manual of Determinative Bacteria meliputi :

\section{a. Bentuk sel}

Pewarnaan bentuk sel digunakan untuk mengetahui apakah isolat mempunyai bentuk batang yang diasumsikan dari genus Bacillus. Isolat diambil 1 ose, kemudian digoreskan di atas kaca objek yang telah diberi akuades sebelumnya. Preparat difiksasi di atas api bunsen. Selanjutnya preparat ditetesi dengan methylene blue sebanyak 1-2 tetes, didiamkan 30 detik. Preparat dibilas dengan akuades dan didiamkan hingga kering. Preparat ditutup dengan kaca penutup dan diberi tambahan minyak imersi sebanyak 1 tetes. Diamati dengan mikroskop perbesaran 1000 kali[9].

\section{b. Sifar gram}

Pengamatan sifat gram untuk mengetahui apakah isolat bersifat Gram positif yang diasumsikan dari genus Bacillus. Isolat diambil sebanyak 1 ose, kemudian digoreskan di atas kaca objek yang telah diberi akuades. Preparat difiksasi di atas api bunsen, lalu ditetesi larutan kristal violet sebanyak 2-3 tetes. Preparat didiamkan 1 menit, dibilas dengan akuades. Preparat ditetesi larutan Gram's iodine sebanyak 2-3 tetes dan didiamkan 1 menit. Selanjutnya preparat dibilas kembali dengan akuades. Preparat didekolorisasi dengan menggunakan etil alkohol $95 \%$ setetes demi setetes selama 20 detik kemudian dibilas kembali dengan akuades dan didiamkan hingga kering. Preparat ditetesi safranin \pm 1 menit dan dibilas kembali dengan akuades, didiamkan hingga kering. Preparat ditutup dengan kaca penutup dan diberi tambahan minyak imersi sebanyak 1 tetes, diamati dengan mikroskop perbesaran 1000 kali [9].

\section{c. Endospora}

Pengamatan endospora digunakan untuk mengamati apakah isolat mampu menghasilkan endospora yang diasumsikan dari genus Bacillus. Isolat diambil sebanyak 1 ose, kemudian digoreskan di atas kaca objek yang telah diberi akuades. Preparat difiksasi di atas bunsen. Selanjutnya bagian atas preparat ditutup kertas saring, ditetesi malachite green hingga menutupi seluruh permukaan kaca objek. Preparat dipanaskan selama 3-4 menit di atas api bunsen dengan bantuan penangas kasa. Selanjutnya kertas saring pada preparat dibuang dan dibilas dengan akuades. Preparat diwarnai dengan safranin \pm 1 menit dan dibilas kembali dengan akuades. Preparat ditutup dengan kaca penutup dan diberi tambahan minyak imersi sebanyak 1 tetes, diamati dengan mikroskop perbesaran 1000 kali[9].

\section{d. Motilitas}

Uji motilitas digunakan untuk mengetahui apakah isolat bersifat motil atau non motil. Uji motilitas dapat diperoleh dari uji produksi $\mathrm{H}_{2} \mathrm{~S}$ dan gas. Hasil uji positif ditandai dengan terbentuknya sebaran pada daerah bekas inokulasi yang berarti bakteri melakukan aktifitas pergerakan (motil)[9].

e. Uji kebutuhan oksigen

Pengamatan kebutuhan oksigen digunakan untuk mengetahui sifat bakteri aerob yang diasumsikan dari genus Bacillus. Dibuat medium Thioglicolat. Isolat berumur 24 jam diambil sebanyak 1 ose kemudian diinokulasikan ke dalam medium Thioglicolat secara aseptis. Selanjutnya inokulum pada tabung reaksi dihomogenkan dengan vortex agar bakteri terdistribusi merata dalam medium. Inokulum diinkubasi selama 48 jam pada suhu ruang, kemudian diamati pola penyebaran bakteri[9].

f. Katalase

Gelas objek yang telah dibersihkan dengan alkohol $70 \%$ ditetesi dengan larutan $\mathrm{H}_{2} \mathrm{O}_{2}$ (Hidrogen Peroksida) $3 \%$ sebanyak 1 tetes. Isolat diambil sebanyak 1 ose lalu digoreskan secara aseptis pada kaca objek. Isolat dihomogenkan secara manual dan diamati hasilnya. Hasil positif ditandai dengan timbulnya gas atau gelembung udara di sekitar goresan isolat bakteri[9].

g. Pengamatan kristal protein

Koloni yang telah tumbuh diinkubasi selama \pm 72 jam hingga proses sporulasi. Selanjutnya dilakukan observasi mikroskopis untuk memastikan terbentuknya kristal protein disertai endospora. Koloni yang dipastikan membentuk kristal protein dipanen dan disimpan pada agar LB miring, diberi nomer isolat[4].

3. Aplikasi Bacilus thuringiensis sebagai biopestisida

a. Persiapan suspensi B. thuringiensis terpilih

Masing-masing isolat $B$. thuringiensis yang sudah disimpan dalam LB miring diambil sebanyak 1 ose dan diinokulasikan pada $10 \mathrm{ml}$ medium LB cair dalam Erlenmeyer, diinkubasi selama 18 jam di atas rotary shaker pada suhu ruang [11]. Selanjutnya kultur B. thuringiensis tersebut dimasukkan ke dalam $90 \mathrm{ml}$ media LB. Diinkubasi selama \pm 72 jam [4] pada suhu ruang di atas rotary shaker. Kepadatan sel yang digunakan untuk uji sebanyak $10^{7}$ $\mathrm{sel} / \mathrm{ml}$ yang dihitung menggunakan Haemocytometer dengan perbesaran 1000 kali [12].

b. Pengujian toksisitas S. litura F.

Sebanyak 10 ekor larva S. litura F. instar 3, 4 dan 5 dimasukkan ke dalam masing-masing wadah plastik berbentuk balok yang berbeda. Pengujian dilakukan dengan 
memberi makan larva $S$. litura $\mathrm{F}$. pada masing-masing wadah dengan dua lembar daun sawi (Brassica rapa L.) yang telah disemprot suspensi $B$. thuringiensis sebanyak 10 kali semprot $( \pm 4 \mathrm{~mL})$. Pemberian makan pada ulat dilakukan selama tujuh hari. Masing-masing perlakuan terdiri atas tiga kali ulangan. Sebagai kontrol digunakan daun $B$. rapa L. yang disemprot dengan akuades steril.

c. Parameter Pengamatan

Pengamatan mortalitas dilakukan terhadap mortalitas larva serangga yang diamati setiap hari selama tujuh hari. Virulensi setiap isolat ditentukan dengan nilai mortalitas pada larva-larva uji menurut [13] menggunakan rumus :

$$
\mathrm{M}=\frac{\mathrm{A}}{\mathrm{B}} \times 100 \%
$$

Keterangan :

$\mathrm{M}=$ mortalitas (\%)

$A=$ jumlah serangga mati pada umur tertentu

$\mathrm{B}=$ jumlah serangga yang diamati

Data hasil pengamatan akan dianalisis dengan tabulasi data dan tingkat virulensi $B$. thuringiensis ditetapkan berdasarkan nilai mortalitas serangga uji menurut [14] yaitu :

a. Virulensi tinggi, jika nilai mortalitas di atas $50 \%$

b. Virulensi sedang, jika nilai mortalitas $30 \%-<50 \%$

c. Virulensi rendah, jika nilai mortalitas $<30 \%$

d. Tidak virulen, jika nilai mortalitas $0 \%$

\section{HASIL DAN PEMBAHASAN}

\section{A. Isolasi dan Purifikasi}

Isolat bakteri berasal dari empat perkebunan di Batu Malang Jawa Timur yaitu perkebunan sawi, bunga, kol dan bawang merah. Medium agar selektif yang digunakan adalah LB (Lurian Bertani) karena menurut [10] medium tersebut dapat menstimulus pertumbuhan spora dan protein kristal. Isolasi menggunakan metode cawan sebar (spread plate) dengan pengenceran sampai dengan $10^{-6}$. Tujuan pengenceran supaya diperoleh isolat yang tidak padat [9]. Koloni yang tumbuh adalah isolat yang diasumsikan sebagai Bacillus.

Hasil seleksi pada koloni tunggal diperoleh 20 isolat, tujuh isolat dari perkebunan kol yaitu $\mathrm{K} 2, \mathrm{~K} 3, \mathrm{~K} 4, \mathrm{~K} 6, \mathrm{~K} 7, \mathrm{~K} 8, \mathrm{~K} 9$, lima isolat dari kebun bunga yaitu KB1, KB4, KB6, KB7, $\mathrm{KB} 8$, lima isolat dari perkebunan sawi yaitu S2, S3, S5, S6, S9 dan tiga isolat dari perkebunan bawang merah yaitu B3, B6, B7. Selanjutnya isolat dipurifikasi dengan metode 16 gores pada cawan agar. Koloni yang seragam menunjukkan keberhasilan purifikasi (Gambar 1).

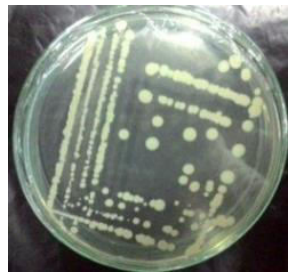

Gambar 1. Koloni Purifikasi dengan Metode 16 Goresan.
Hasil purifikasi untuk masing-masing isolat diamati selnya dengan pewarnaan sederhana methylene blue. Sel yang telah seragam menunjukkan bahwa sel diasumsikan terdiri dari satu genus (Gambar 2).

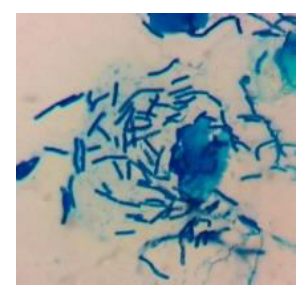

Gambar 2. Pengamatan Sel dengan Pewarnaan Methylene Blue (Perbesaran 1000x).

\section{B. Generic Assigment}

Menurut [15], Identifikasi dan generic assignment digunakan untuk mengidentifikasi apakah isolat termasuk anggota genus yang sudah ada atau genus baru. Identifikasi dilakukan dengan menggunakan panduan Bergey's Manual of Determinative Bacteriology [16]. Hasil Identifikasi terhadap 20 isolat menggunakan profile matching dengan karakter kunci sesuai genus Bacillus dapat dilihat pada (Tabel 1).

Tabel 1 .

Identifikasi dengan Profile Matching berdasarkan karakter kunci genus Bacillus

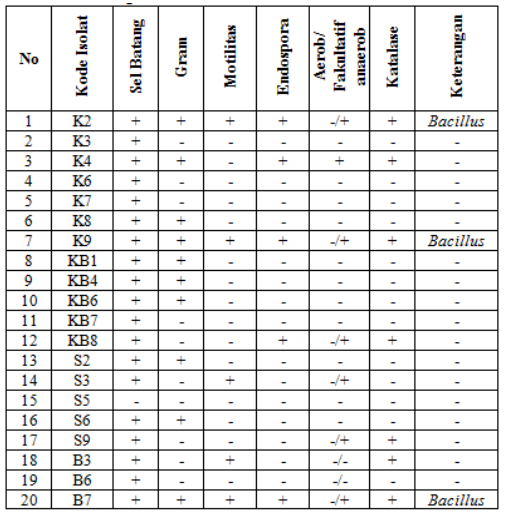

Berdasarkan Tabel 4.1 menggunakan profile matching dengan karakter kunci genus Bacillus maka isolat K2, K9 dan B7 diidentifikasi sebagai genus Bacillus yang mempunyai karakter sel berbentuk batang, Gram positif, motil, memiliki endospora, bersifat aerob/fakultatif anaerob dan katalase positif. Menurut [16], genus Bacillus mempunyai karakter kunci sel batang, Gram positif, motil, memiliki endospora, bersifat aerob/fakultatif anaerob dan katalase positif. Untuk menentukan bahwa isolat adalah Bacillus thuringiensis maka dilakukan uji terbentuknya kristal protein.

\section{Pengamatan Kristal Protein}

Isolat K2, K9 dan B7 yang sudah teridentifikasi sebagai genus Bacillus, selanjutnya diuji dengan ciri spesifik terbentuknya endospora dan kristal protein. Isolat $\mathrm{K} 2$, $\mathrm{K} 9$ dan B7 dapat membentuk endospora tetapi hanya isolat K2 dan K9 yang mampu membentuk endospora sekaligus membentuk kristal protein. (Gambar 3). 


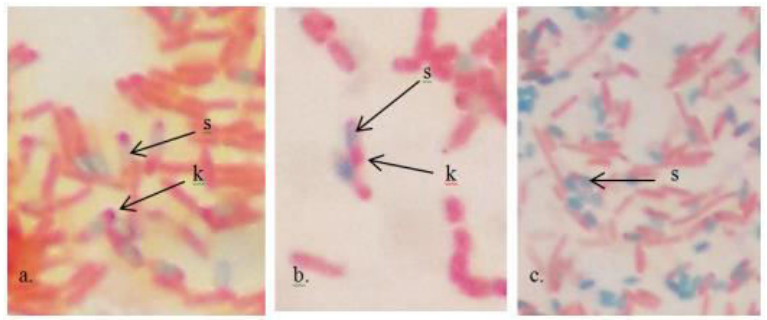

Gambar 3. (a) Sel B. thuringiensis isolat $\mathrm{K} 2$, (b) B. thuringiensis isolat $\mathrm{K} 9$, (c) B. thuringiensis isolat B7 yang tidak membentuk kristal protein. Pengamatan dilakukan dengan mikroskop cahaya pada perbesaran 1000x. k= kristal, $\mathrm{s}=$ endospora.

Kristal protein adalah ciri khas dari bakteri B. thuringiensis. Kemampuannya membentuk kristal bersamaan dengan pembentukan spora, yaitu pada waktu sel mengalami sporulasi. Kristal tersebut merupakan kompleks protein yang mengandung toksin ( $\delta$-endotoksin) yang terbentuk di dalam sel 2-3 jam setelah akhir fase eksponensial dan baru keluar dari sel pada waktu sel mengalami sporulasi [17]. Selanjutnya untuk aplikasi pembuatan bioinsektisida yang digunakan adalah isolat $\mathrm{K} 2$ dan $\mathrm{K} 9$.

Kepadatan sel B. thuringiensis yang digunakan sebagai bioinsektisida adalah $10^{7}$. Berdasarkan hasil penelitian sebelumnya yang dilakukan oleh [18], isolat B. thuringiensis yang memiliki potensi terbaik dalam membunuh larva Aedes aegypti mempunyai kepadatan $10^{7} \mathrm{sel} / \mathrm{ml}$.

\section{Aplikasi B. thuringiensis terhadap larva S. litura F.}

Hasil uji toksisitas isolat K2 dan K9 terhadap larva S. litura instar 3, 4 dan 5 dapat dilihat pada Tabel 4.3. Isolat K2 dan K9 dapat bertindak sebagai bioinsektisida karena dapat membunuh larva $S$. litura pada stadium instar 3, 4 dan 5. Isolat K9 lebih tinggi persen membunuhnya dibandingkan isolat $\mathrm{K} 2$ (Tabel 2)

Tabel 2.

Hasil Uji Toksisitas Isolat K2 dan K9 terhadap S. litura

\begin{tabular}{|c|c|c|c|c|c|c|c|c|c|c|}
\hline \multirow[t]{2}{*}{ Instar } & \multirow{2}{*}{$\begin{array}{l}\text { Per- } \\
\text { lakuan } \\
\text { Isolat }\end{array}$} & \multicolumn{7}{|c|}{$\begin{array}{c}\text { Rata-rata Mortalitas } \\
\text { Larva hari ke- }\end{array}$} & \multirow{2}{*}{$\begin{array}{c}\% \\
\text { Mortalitas } \\
\text { Larva }\end{array}$} & \multirow{2}{*}{$\begin{array}{l}\text { Tingkat } \\
\text { Virulensi }\end{array}$} \\
\hline & & 1 & 2 & 3 & 4 & 5 & 6 & 7 & & \\
\hline \multirow[t]{3}{*}{3} & Kontrol & - & - & 1 & 2 & 2 & 3 & 4 & $40 \%$ & - \\
\hline & $\mathrm{K} 2$ & - & - & 2 & 3 & 6 & 7 & 7 & $70 \%$ & Tinggi \\
\hline & K9 & 1 & 3 & 4 & 5 & 7 & 8 & 8 & $80 \%$ & Tinggi \\
\hline \multirow[t]{3}{*}{4} & Kontrol & - & - & 1 & 2 & 3 & 3 & 4 & $40 \%$ & - \\
\hline & $\mathrm{K} 2$ & - & - & 1 & 1 & 5 & 7 & 7 & $70 \%$ & Tinggi \\
\hline & K9 & - & - & 2 & 3 & 6 & 8 & 9 & $90 \%$ & Tinggi \\
\hline \multirow[t]{3}{*}{5} & Kontrol & - & - & 2 & 3 & 4 & 5 & 5 & $50 \%$ & - \\
\hline & $\mathrm{K} 2$ & - & 1 & 4 & 5 & 7 & 8 & 10 & $100 \%$ & Tinggi \\
\hline & K9 & - & 1 & 3 & 4 & 7 & 8 & 10 & $100 \%$ & Tinggi \\
\hline
\end{tabular}

Pada kontrol terjadi kematian larva $S$. litura instar 3, 4 dan 5 yang dimulai hari ketiga setelah aplikasi. Hal ini kemungkinan disebabkan oleh tidak terkontrolnya faktor lingkungan saat larva dikirim dari tempat pemesanan sehingga dengan lingkungan baru mengalami tingkat stress yang dialami larva S. litura.

Isolat K9 mulai aktif membunuh pada hari pertama aplikasi sedangkan isolat $\mathrm{K} 2$ mulai aktif membunuh pada hari kedua setelah aplikasi sehingga isolat K9 lebih toksin dari isolat K2. B. thuringiensis diduga sudah masuk ke dalam saluran bagian tengah menjadi molekul yang toksin sehingga mematikan larva S. litura. Menurut [19], bila spora dan kristal protein dimakan oleh serangga yang peka maka akan terjadi paralisis yang mengakibatkan kematian inang. Kristal bakteri akan larut dalam saluran pencernaan dan mengeluarkan toksin yang dapat mematikan serangga.

Isolat K9 lebih cepat membunuh larva $S$. litura dibandingkan isolat K2. Menurut [20], adanya perbedaan toksisitas dapat disebabkan oleh beberapa faktor antara lain $\mathrm{pH}$ usus target, yaitu usus target tidak dapat melarutkan kristal protein dalam usus tengah. Ukuran kristal protein sangat menentukan konsentrasi toksin yang larut dalam usus tengah serangga. Bila ukuran kristal protein besar, maka konsentrasi kristal protein yang terlarut juga besar. Pada penelitian ini tidak dilakukan pengukuran $\mathrm{pH}$ usus dan ukuran kristal protein.

Mortalitas tertinggi terjadi pada larva S. litura instar 5. Hal tersebut dimungkinkan karena laju konsumsi larva tiap instar berbeda-beda sehingga distribusi spora tidak merata. Laju konsumsi larva $S$. litura instar 5 lebih banyak dibandingkan dengan larva instar $S$. litura 3 dan 4 . Hal tersebut dapat diketahui dari sisa daun Brassica rapa pada kotak yang berisi larva $S$. litura. Kotak instar 5 paling sedikit menyisakan makanan dibandingkan dengan kotak yang berisi larva $S$. litura instar 3 dan 4. Pada hari ke tujuh perlakuan kontrol, larva $S$. litura lebih banyak yang hidup dibandingkan dengan perlakuan K2 dan K9.

Larva $S$. litura yang mati akibat perlakuan B. thuringiensis dapat diamati dengan ciri-ciri fisik seperti tubuh berwarna coklat atau hitam, mengkerut, melengkung, kering dan kaku. Selain itu, perilakunya menjadi lamban dan akhirnya berhenti bergerak dan kadang-kadang mengeluarkan cairan hijau dari mulutnya kemudian kotorannya menjadi berair (diare) dan akhirnya akan mati dengan tubuh menjadi lembek. Menurut [17], gejala serangan bakteri pada serangga diawali dengan tanda-tanda tidak aktif, nafsu makan berkurang, lemah, serangga mengalami diare dan keluar cairan dari beberapa bagian tubuh. Bangkai larva uji dalam penelitian ini berbau busuk dan semakin hari semakin mengecil. Selanjutnya larva $S$. litura tersebut mulai hancur. Hal ini diperkuat dengan pendapat yang disampaikan oleh [21] yang menemukan bahwa larva yang terinfeksi bakteri $B$. thuringiensis tubuhnya mengalami pembengkakan dan berwarna hitam kecoklatan serta dalam waktu beberapa hari akan mengalami kehancuran. Sedangkan larva $S$. litura yang mati akibat perlakuan kontrol dalam penelitian ini mempunyai ciri-ciri fisik yang masih bagus dan normal (Gambar 4)

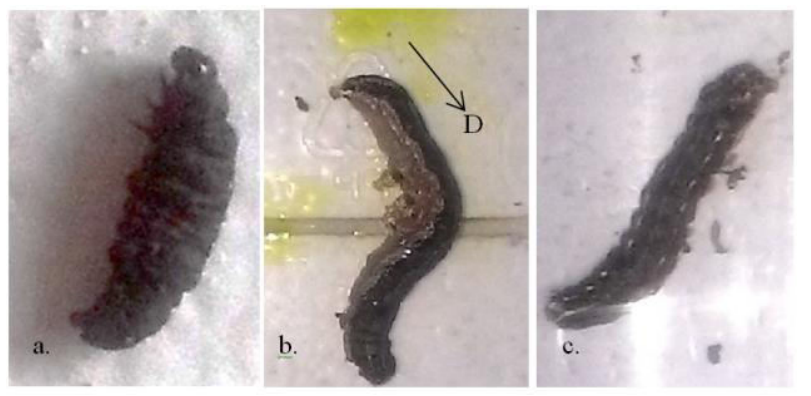

Gambar 4. Larva S. litura yang mati akibat perlakuan B. thuringiensis, (a) berwarna hitam, kering dan kaku, (b) larva mengalami diare sebelum akhirnya mati, (c) larva yang mati akibat perlakuan kontrol. $\mathrm{D}=$ diare 
Menurut [22], serangga yang peka terhadap bakteri $B$. thuringiensis termasuk mempunyai saluran pencernaan yang bersifat alkali, menghasilkan mineral dan enzim yang dapat menghidrolisis kristal protoksin menjadi toksin. Komponen toksin B. thuringiensis disebut delta endotoksin. Delta endotoksin berikatan dengan sel yang menempel pada dinding membran usus membentuk lubang pada membran dan mengganggu keseimbangan ion dalam usus. Larva serangga akan berhenti makan kemudian mati [23]. Pembengkakan disebabkan oleh banyaknya kation yang memasuki sel epitel melalui pori-pori yang dibentuk toksin yang diduga spesifik terhadap kation seperti $\mathrm{K}^{+}$dan $\mathrm{Na}^{+}$. Banyaknya kation dalam sel menyebabkan ketidakseimbangan osmotik sehingga menyebabkani lisis [8].

Berdasarkan Tabel 4.3 pada kontrol setelah hari ke tujuh, larva instar 3, 4 dan 5 masih hidup. Hal ini menunjukkan bahwa pada kontrol benar-benar tidak ada pengaruh $B$. thuringiensis. Setelah hari ke tujuh larva instar 3, 4 dan 5 mempunyai persentase hidup $>50 \%$. Hal ini disebabkan larva mengalami stress pada pengiriman dari lokasi uji Balai Penelitian Tanaman Pemanis dan Serat Malang.

\section{KESIMPULAN}

Bakteri B. thuringiensis yang diisolasi dari tanah perkebunan di daerah Batu Malang dapat membunuh larva $S$. litura $\mathrm{F}$. Isolat $\mathrm{K} 9$ mempunyai daya bunuh terhadap larva $S$. litura $\mathrm{F}$ lebih tinggi dibandingkan dengan isolat $\mathrm{K} 2$. Isolat $\mathrm{K} 9$ sudah menyebabkan mortalitas mulai hari pertama dan pada hari ke tujuh persentase kematiannya $\geq 80 \%$. Sedangkan pada isolat K2 mulai terjadi mortalitas larva S. litura F pada hari ke dua setelah aplikasi dan pada hari ke tujuh persentase kematiannya $\geq 70 \%$.

\section{UCAPAN TERIMAKASIH}

Penulis mengucapkan terimakasih kepada Dr. Enny Zulaika, MP. atas dukungannya melalui pendanaan PNBP ITS tahun anggaran 2016 No. Kontrol 01711/IT2.11/PN.08/2016.

\section{DAFTAR PUSTAKA}

[1] J. H. Laoh, F. Puspita, and Hendra, "Kerentanan Larva Spodoptera litura F. terhadap Virus Nuklear Polyhedrosis," J. Natur Indones., vol. 5, no. 2, pp. 145-151, 2003.

[2] K. Untung, Dasar-Dasar Pengelolaan Hama Terpadu. Yogyakarta: Universitas Gadjah Mada, 1996

[3] D. Sande, J. Mullen, M. Wetzstein, and J. Houston, "Environmental Impacts from Pesticide Use: A Case Study of Soil Fumigation in Florida Tomato Production," Int. J. Environtmental Res. Public Heal., 2011.
[4] S. Hermanto, E. Jusuf, and M. H. Shiddiqi, "Eksplorasi Protein Toksin Bacillus thuringiensis dari Tanah di Kabupaten Tangerang," Valensi, vol. 3, no. 1, pp. 48-56, 2013.

[5] H. Hofte and H. R. Whiteley, "Insecticidal Crystal Proteins of Bacillus thuringiensis," Microbiol. Rev., vol. 53, no. 2, pp. 242-255, 1989.

[6] Bahagiawati, "Penggunaan Bacillus thuringiensis sebagai Bioinsektisida," Bul. Agrobio, vol. 5, no. 1, pp. 21-28, 2002.

[7] V. N. Jisha, R. B. Smitha, and S. Benjamin, "An Overview on the Crystal Toxins from Bacillus thuringiensis," J. Adv. Microbiol., vol. 3, pp. 462472, 2013.

[8] Y. Tanada and H.K. Kaya, Insect Pathology. New York: Academic Press, 1993.

[9] J. P. Harley and L. M. Prescott, Laboratory Exercises in Microbiology. USA: The McGraw-Hill Companies, 2002.

[10]S. Muharsini and A. H. Wardhana, "Uji Efikasi Isolat Lokal Bacillus thuringiensis yang mempunyai Gen Cry terhadap Lalat Chrysomya Bezziana secara In Vitro," in Seminar Nasional Teknologi Peternakan dan Veteriner 2005, 2005.

[11]E. Zulaika, U. Sholikah, and A. Prasetya, "Potensi Bakteri Bacillus sebagai Agensia Bioremediasi Limbah Industri yang Mengandung Merkuri," Institut Teknologi Sepuluh Nopember, 2012.

[12]E. A. Martin, Oxford Concise Medical Dictionary, 7th ed. New York: Oxford University Press, 2007.

[13]A. Khaeruni, Rahayu, and N. T. Purnamaningrum, "Isolasi Bacillus thuringiensis BERL. dari Tanah dan Patogenitasnya terhadap Larva Crocidolomia binotalis ZELL. pada Tanaman Sawi (Brassica juncea L.)," J. Agroteknos Maret, vol. 2, no. 1, pp. 21-27, 2012.

[14]I. Rusmana and R. S. Hadioetomo, "Isolasi Bacillus thuringiensis Berl. dari Peternakan Ulat Sutera dan Toksisitasnya terhadap Larva Crocodolomia binotalis Zell. dan Spodoptera litura F," Hayati, vol. 1, no. 1, pp. 21-23, 1994.

[15]E. Zulaika, "Eksplorasi Bakteri Resisten Merkuri (BRM) Endogenik Kalimas Surabaya yang Berpotensi sebagai Kandidatus Agensia Bioremediasi Pencemaran Merkuri," Universitas Airlangga, 2013.

[16]J. G. Holt, N. R. Krieg, P. H. A. Sneath, J. . Staley, and S. . Williams, Bergey's Manual of Determinative Bacteriology. Philadelphia: Lippincot Williams \& Wilkins, 1994

[17] Trizelia, "Pemanfaatan Bacillus thuringiensis untuk pengendalian hama Crocidolomia binotalis," Institut Pertanian Bogor, 2001.

[18]E. K. Pratiwi, S. Samino, Z. P. Gama, and N. Nakagoshi, "Uji Toksisitas Bacillus thuringiensis Asal Kota Nganjuk terhadap Larva Aedes aegypti," J. Biotropika, vol. 1, no. 4, 2013.

[19] M. Hadi, T. Udi, and R. Rully, Biologi Insekta Entomologi. Yogyakarta: Graha Ilmu, 2009.

[20]D. Lantang and D. Y. Runtuboi, "Karakterisasi Bakteri Bacillus thuringiensis asal Hutan Lindung Kampus Uncen Jayapura, serta Deteksi Toksisitasnya terhadap Larva Nyamuk Anopheles," J. Biol. Papua, vol. 4, no. 1, pp. 19-24, 2012.

[21]C. P. Blondine and U. Widyastuti, "Patogenitas Isolat Bacillus thuringiensis setelah Dikeringkan pada Suhu Dingin (Lyophilisasi) terhadap Jentik Aedes aegypty di Laboratorium," Dunia Kedokt., vol. 131, pp. 10-12, 1997.

[22]Z. P. Gama, N. Nakagoshi, Suharjono, and F. Setyowati, "Toxicity studies for indigenous Bacillus thuringiensis isolates from Malang city, East Java on Aedes aegypti Larvae," J. Trop. Biomed, vol. 13, 2013.

[23]A. Bravo, S. S. Gill, and M. Soberon, "Mode of Action of Bacillus thuringiensis Cry and Cyt toxins and Their Potential for Insect Control," Toxicon, vol. 49, no. 4, p. 423-435., 2007. 